\title{
Operational Improvement of Hemire ROV for Deep-sea Survey and Application to Exploration of Ferromanganese Crusts of Western Pacific Seamount
}

\author{
Hyuk Baek*, Jin-Yeong Park*, Hyungwon Shim*, Bong-Huan Jun* and Pan-Mook Lee®* \\ "Marine ICT Research Division, KRISO, Daejeon, Korea
}

\section{해미래의 심해탐사 운용기법 개선 및 서태평양 해저산 망간각 탐사에 적용}

\author{
백혁* • 박진영* 심형원 · 전봉환 ${ }^{*}$ 이판묵(1) \\ "선박해양플랜트연구소 해양두연구본부
}

KEY WORDS: Remotely operated vehicle(ROV) 원격조종 무인잠수정, Operational improvement 운용 개선, Cable termination 케이블 연결, Cooling plugs 냉각 플러그, Seamount survey 해저산 탐사

\begin{abstract}
This paper presents the results of an exploration of the ferromanganese crusts of Western Pacific Seamount registered by the Korean government. This area has been surveyed with a deep-sea camera and crust samples have been acquired by deep-sea dredging since 2013. On October 18-19, 2017, a united research team from KIOST and KRISO explored two blocks, OSM11 and OSM07, on the seamount using Hemire ROV. A precise survey was conducted on the ferromanganese crusts and sediments covering the slope/top of OSM11 and the middle flat area of OSM07. Rock samples were collected with precise positioning, and HD videos were recorded for 7 hours. This paper discusses the technical issues of this exploration in terms of (1) how to deal with an emergency situation during an electric power blackout, (2) the improvement of the thruster power by adding cooling plugs to the housings of the thruster amplifiers, (3) the relative motion of the depressor by changing the fixing method of the cable terminator, which affects the service life of the cable, (4) a sampling technique for the steep slope of the seamount, (5) integrated navigation under a USBL blackout, and (6) a 3-dimensional image mosaic for visualizing the distribution state of the crusts.
\end{abstract}

\section{1. 서 론}

한국해양과학기술원에서는 미개척 해양자원인 해양광물자원 (해저열수광상, 망간각)의 개발가능지역을 조사하여 탐사광구 (공해) 및 탐사권을 확보하고자, 연구선 온누리호를 이용한 서 태평양 해저산의 고코발트 망간각 탐사를 수행했다(Moon et al., 2014; Moon et al., 2015; Moon et al., 2016). 수행한 탐사에서 영 상 촬영은 심해저카메라 시스템(Deep sea camera)을 이용하였고, 시료채집은 드렛지(Dredge)를 이용했다. 심해저 카메라 시스템 은 연구선의 윈치케이블을 이용한 견인형 시스템이므로 파고에 의한 연구선의 수직운동이 카메라의 해상도에 영향을 주었고, 사면과 충돌을 피하기 위해 약 $5 \sim 10 \mathrm{~m}$ 높이를 유지해야 하므로 사면의 연속촬영과 미소 지형 변화에 따른 정밀 망간각 피복 특성 파악에 어려움이 있었다. 또한, 시료채집에 있어서도 드렛
지에 의존하므로 채집된 시료의 위치를 정밀히 파악하는 것에 는 한계가 있었다.

과학탐사용 ROV(Remotely operated vehicle)는 종래의 연구선 단독 탐사에서 가지고 있던 해저산 사면의 정밀 영상촬영과 정 위치 시료채집의 한계를 극복할 수 있는 효과적인 대안이다. 2017년 10월 18일과 19일 두 차례에 걸쳐 Fig. 1에서 도시한 두 지역에 과학탐사용 ROV인 해미래를 투입했다(Baek et al., 2017). 2017년 10월 18일에는 OSM11지역을 그리고, 2017년 10 월 19 일에는 OSM07지역의 해저면 영상촬영과 시료채집 탐사를 수행했다. OSM11지역에서는 수심 2,100m에서 정상부 수심인 $1,454 \mathrm{~m}$ 까지 지형이 높아지는 해저산의 사면을 따라 약 4 시간 10 분간 정밀 망간각 피복의 영상관찰을 수행했고, 5 개 지점에서 암석시료 각 1 개씩 채집하여 총 5 개를 채집했다. OSM07지역에 서는 해저산 중턱의 평탄면인 수심 약 $2,500 \mathrm{~m}$ 에서 약 $2 \mathrm{~km}$ 를 이

Received 10 May 2018, revised 1 July 2018, accepted 2 August 2018

Corresponding author Pan-Mook Lee: +82-42-866-3810, pmlee@kriso.re.kr ORCID: https://orcid.org/0000-0002-0500-6167

It is noted that this paper is revised edition based on proceedings of Korea Marine Robot Technology Society(KMRTS) 2017 in Pohang.

(c) 2018, The Korean Society of Ocean Engineers

This is an open access article distributed under the terms of the creative commons attribution non-commercial license (http://creativecommons.org/licenses/by-nc/3.0) which permits unrestricted non-commercial use, distribution, and reproduction in any medium, provided the original work is properly cited. 


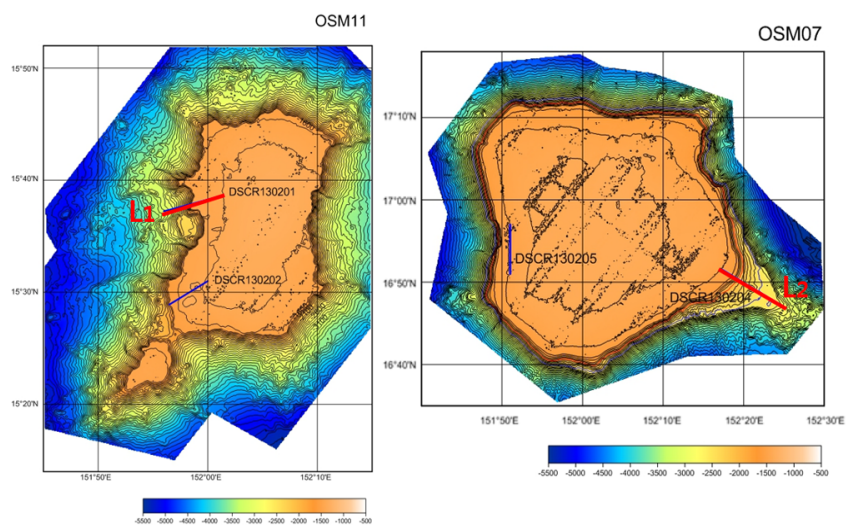

Fig. 1 Manganese cluster zone of the seamount OSM11 \& OSM07

동하며 3 시간 16 분간 영상을 촬영했다.

본 논문에서는 심해저 광물자원 정밀 탐사에 있어서 기존 연 구선 이용법의 한계를 뛰어넘는 방법으로써 ROV를 이용한 국 내 첫 탐사 사례를 소개하고자 한다. 2장에서는 탐사 임무와 해 미래의 개선된 사항을 간략히 소개하고, 3장에서는 OSM11과 OSM07의 두 탐사 위치(Moon et al., 2014)에서 해미래가 취득한 데이터를 소개한다. 4장에서는 운용 중 취득한 해미래 데이터의 검토 결과를 제시하였고, 마지막 5 장에서 결론을 작성하였다.

\section{2. 탐사 임무 및 개선 사항}

\section{1 탐사 임무}

서론에서 설명한 것과 같이 본 연구의 탐사 임무는 ROV를 이용하여 종래의 연구선 단독 해저탐사에서의 한계를 극복하는 것이다. OSM11 지역에서 해저산 사면 경계부 정밀 영상탐사의 목적과 방법 그리고 효과는 다음과 같다.

(1) 목적: 해저산 정상부와 사면 경계부 변화에 따른 망간각 피복의 정밀 영상탐사 및 정위치 망간각 시료 획득

(2) 방법: 정상부와 사면 경계부를 포함하는 측선(약 $1.8 \mathrm{~km})$ 을 따라 해저면 근접 영상탐사와 정위치 시료채집

(3) 효과: 경계부에서의 지형변화에 따른 망간각 분포특성을 파악

OSM07 지역에서 해저산 중간 평탄면 퇴적물 분포 특성 탐사 의 목적과 방법 그리고 효과는 다음과 같다.

(1) 목적: 해저산 중간 평탄면 퇴적토 관측 및 시료 채집

(2) 방법: 중간 평탄면을 따라 연속해서 해저면 근접 영상탐사 및 정위치 퇴적토 시료 획득

(3) 효과: 퇴적물의 연흔(물결 자국, Ripple mark) 방향 분석을 통하여 해저면 인근 해수 흐름의 정성적 판단이 가능하므로 광 구 개발시 광미(Mine tailing) 이동 방향의 예측에 도움이 됨

\section{2 개선 사항}

지난 2016년도 해미래의 마리아나 해저화산 열수분출공 탐사 에서 장시간 운용 중에 두 가지 문제가 발생되었다.

첫째 문제는 해누비의 1 차 케이블 절연저항 파괴이다. 해누비 는 강철 프레임을 용접한 구조물로 되어있고, 설치된 센서와 장 착장비 등의 부가물은 위에서 내려다보았을 때 전후, 좌우 비대

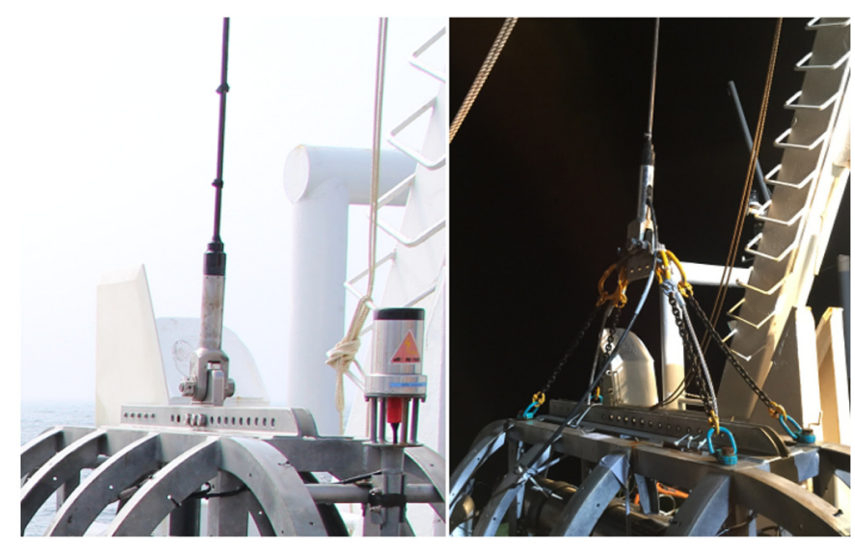

Fig. 2 1-point Hinge connection (left), 4-point wire connections (right)

칭으로 설치되어 있다. 따라서 지원모선에서 1 차 케이블로 직결 된 해누비는 지원모선의 상하운동에 의해 롤(Roll)/피치(Pitch)/ 선수각(Yaw) 운동이 복합적으로 발생된다. 특히 이 운동은 탐사 하는 동안 계속해서 발생되며, 기존의 해누비 상부에 설치된 1 차 케이블 터미네이션은 힌지형태로 설치되어 롤운동과 선수각 운동에 의한 힘은 터미네이션 인근의 1 차 케이블에 가해졌다. 지난 탐사에서 장시간 운영시 절연저항이 낮아지는 현상을 관 찰할 수 있었으며, 절연저항 파괴시 약 12 시간이 소요되는 터미 네이션 교체작업을 해야 하는 문제가 있어왔다. Fig. 2의 좌측은 기존의 1 차 케이블 터미네이션이 힌지 조인트를 통해 해누비에 연결되어 있는 모습을 나타내고, 우측은 1차 케이블 터미네이션 과 해누비 사이에 4 개의 체인을 설치하여, 해누비의 운동이 1 차 케이블 터미네이션에 전달되지 않도록 개선한 모습을 나타낸다. 자세한 실험 데이터의 분석은 4.2장에서 다루었다.

두 번째 문제는 모터앰프의 과열로 인한 에러 발생이다. 이런 에러는 추진기 회전 속도가 명령 값에 도달하지 못하게 만들어 해미래의 운동 응답성능이 떨어지는 주요 요인이 된다. 기존의 모터앰프 내압용기는 총 3 개의 모터앰프가 내압용기 가운데 설 치된 한 개의 지지판 양쪽에 설치되고, 모터앰프에서 발생된 열 이 지지판을 통해 결합된 양쪽 압력용기의 뚜껑으로 방출되는 형태였다. 하지만, 외부로 열을 빼내는 접촉 면적이 작아 열을 빼내는 데는 한계가 있었다. 이를 개선하기 위해 기존 사례 (McDonald and Naiman, 2002)를 참고하여 신규 모터앰프 압력 용기에는 히트파이프(Heat pipe)를 채용했다. Fig. 3과 같이 개선 된 방열구조 모터앰프 내압용기는 지지판의 두께를 늘려 열전 도에 의한 열포화를 피하고, 지지판 내 4개의 히트파이프를 삽 입하여 뚜껑을 관통하도록 설계하고, 뚜껑 외부로 돌출한 히트 파이프는 냉각 플러그(Cooling plugs)와 연결함으로써, 외부 해 수를 이용한 수냉식 방열이 이루어지도록 개선하였다. 모터 앰 프의 방열구조를 개선함으로써 추진기의 회전속도 범위를 넓게 활용할 수 있었다. 기존에는 모터 회전속도를 900rpm(Round per minute)으로 명령하면 과열로 인하여 수분 안에 모터 앰프가 트 립되곤 했으며, 이런 이유로 잠항/부상 또는 전진 시 700rpm 이 상 올라가지 않도록 제한을 두었었다. 그러나 방열구조 개선 이 후인 해저산 망간각 탐사 시에는 모터 회전속도를 900rpm으로 1 시간 이상 지속하여도 온도 상승에 의한 트립이 발생하지 않 았다. 

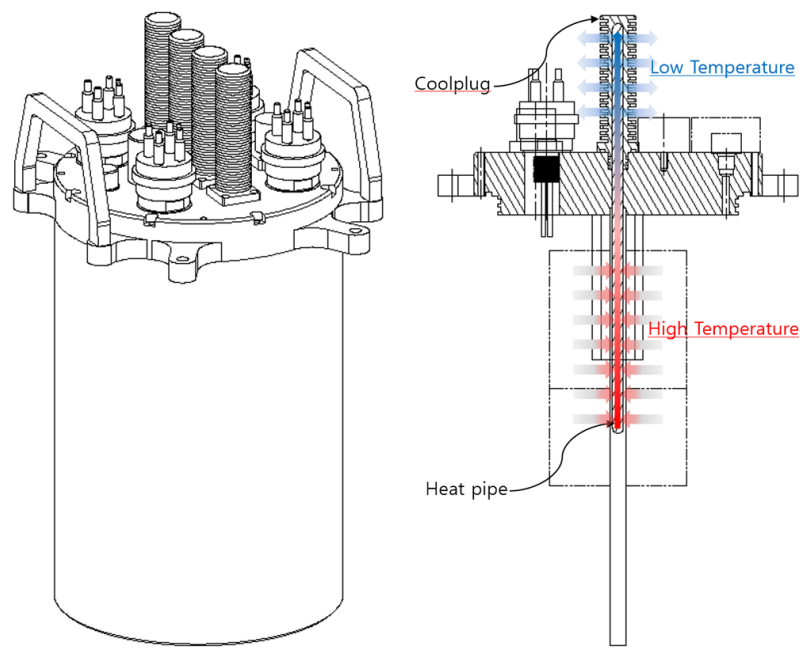

Fig. 3 Four heat pipe CoolPlugs through an end-cap

\section{3. 해저산 망간각 탐사}

\subsection{OSM11 해저산 경사면 탐사}

OSM11 해저산 경사면 탐사는 $2,100 \mathrm{~m}$ 수심부터 $1,450 \mathrm{~m}$ 수심 까지 약 $1.5 \mathrm{~km}$ 수평거리를 이동하며 망간각 상태를 관측하였다.

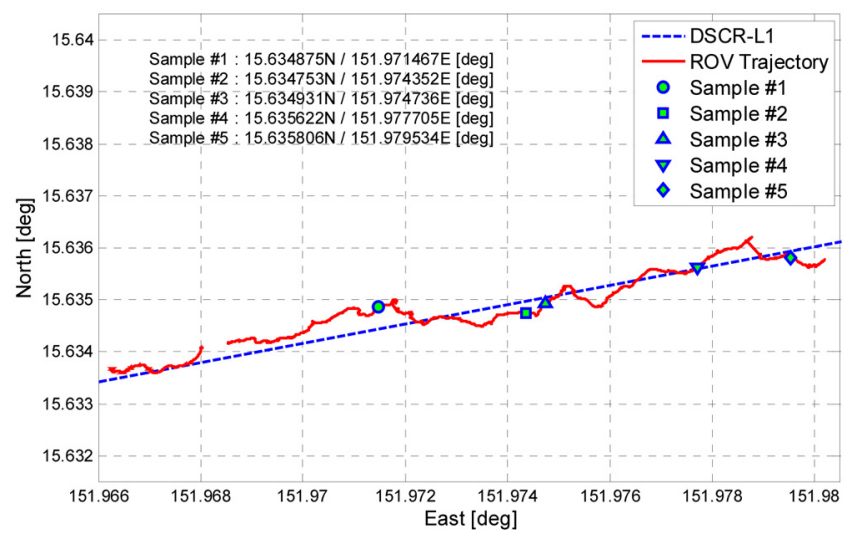

Fig. $4 \mathrm{X}-\mathrm{Y}$ plane trajectory of Hemire in the OSM11 survey
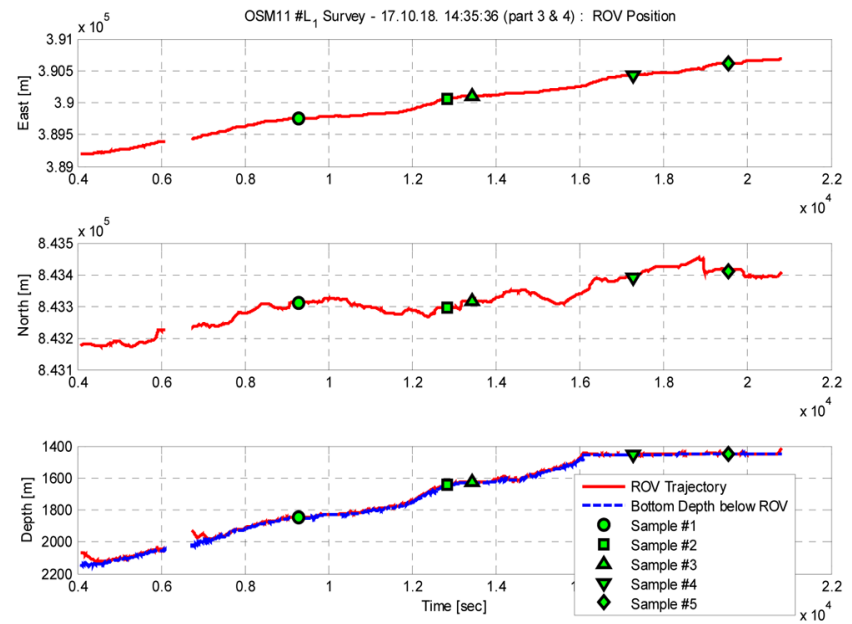

Fig. $5 X, Y, Z$ time series of Hemire in the OSM11 survey
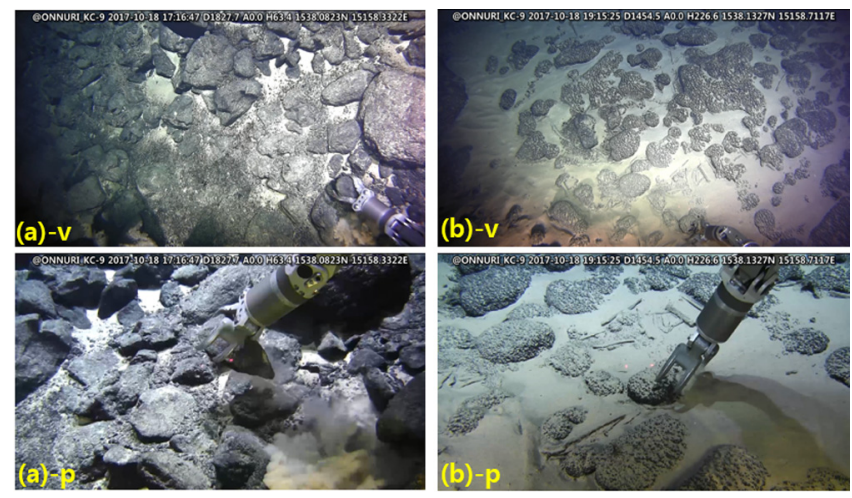

Fig. 6 Manganese cluster at the slope and the top of OSM11

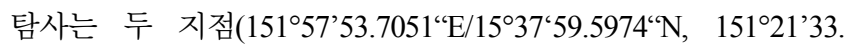
$0283^{\circ `} \mathrm{E} / 15^{\circ} 38^{\prime} 17.8255^{\circ} \mathrm{N}$ )을 기준으로 정해 이 방향으로 경사면 을 따라 이동하며 특이 지점에서 암석시료 5 개를 채집했다. Fig. 4는 X-Y 평면의 해미래 이동경로를 나타내며, Fig. 5는 탐사과 정의 위경도와 심도 변화를 시계열로 나타낸다. Fig. 6은 해저산 경사면의 망간각 분포상황을 나타내는 영상이다. Fig. 6의 좌측 (a)는 경사면에서의 암석시료 \#1 채집장면을 기록한 수직카메라 와 파일럿카메라 영상이며, Fig. 6의 우측(b)는 해저산 정상부의 망간각 분포상황을 보인다. 망간각은 대부분 바닥에 고착되어 있었다. Fig. 6의 우측 그림은 채집이 가능해 보이는 암석을 로 봇팔로 떼어내기를 시도하였으나 실패하는 장면이다.

Fig. 7은 채집된 5개 암석시료를 나타내며, 채집 위치는 다음 Table 1과 같다. 망간각 부존지역에서 ROV를 이용하여 직접 관 측하며 확인된 지점에서 암석시료를 채집한 것은 국내에서 처 음이며, 자원에 대한 새로운 정보를 제공할 것으로 기대된다.

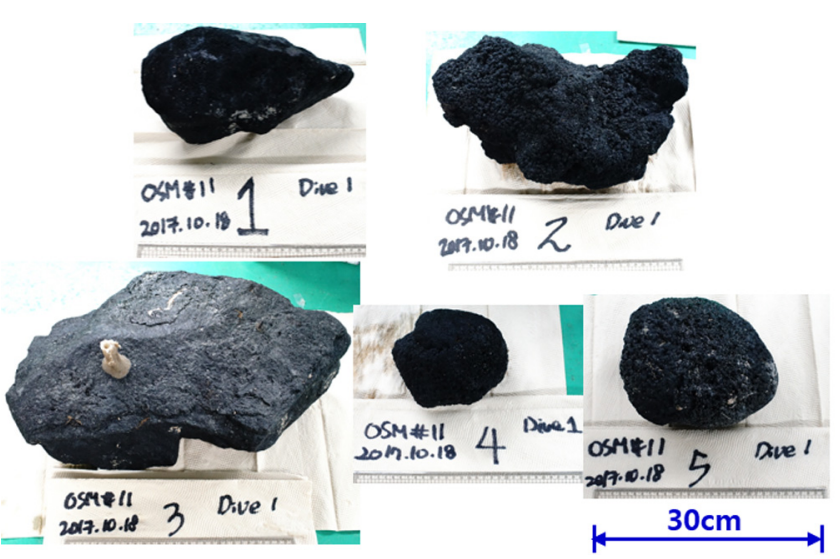

Fig. 7 Rock samples collected at the OSM11 Line-1 survey

Table 1 Location of rock samples

\begin{tabular}{cccc}
\hline \hline No. & Latitude [deg] & Longitude [deg] & Time \\
\hline 1 & $15.63487465 \mathrm{~N}$ & $151.97146718 \mathrm{E}$ & $17: 18: 00$ \\
2 & $15.63475257 \mathrm{~N}$ & $151.97435198 \mathrm{E}$ & $18: 17: 00$ \\
3 & $15.63493063 \mathrm{~N}$ & $151.97473560 \mathrm{E}$ & $18: 27: 00$ \\
4 & $15.63562188 \mathrm{~N}$ & $151.97770475 \mathrm{E}$ & $19: 31: 00$ \\
5 & $15.63580554 \mathrm{~N}$ & $151.97953428 \mathrm{E}$ & $20: 09: 00$ \\
\hline
\end{tabular}




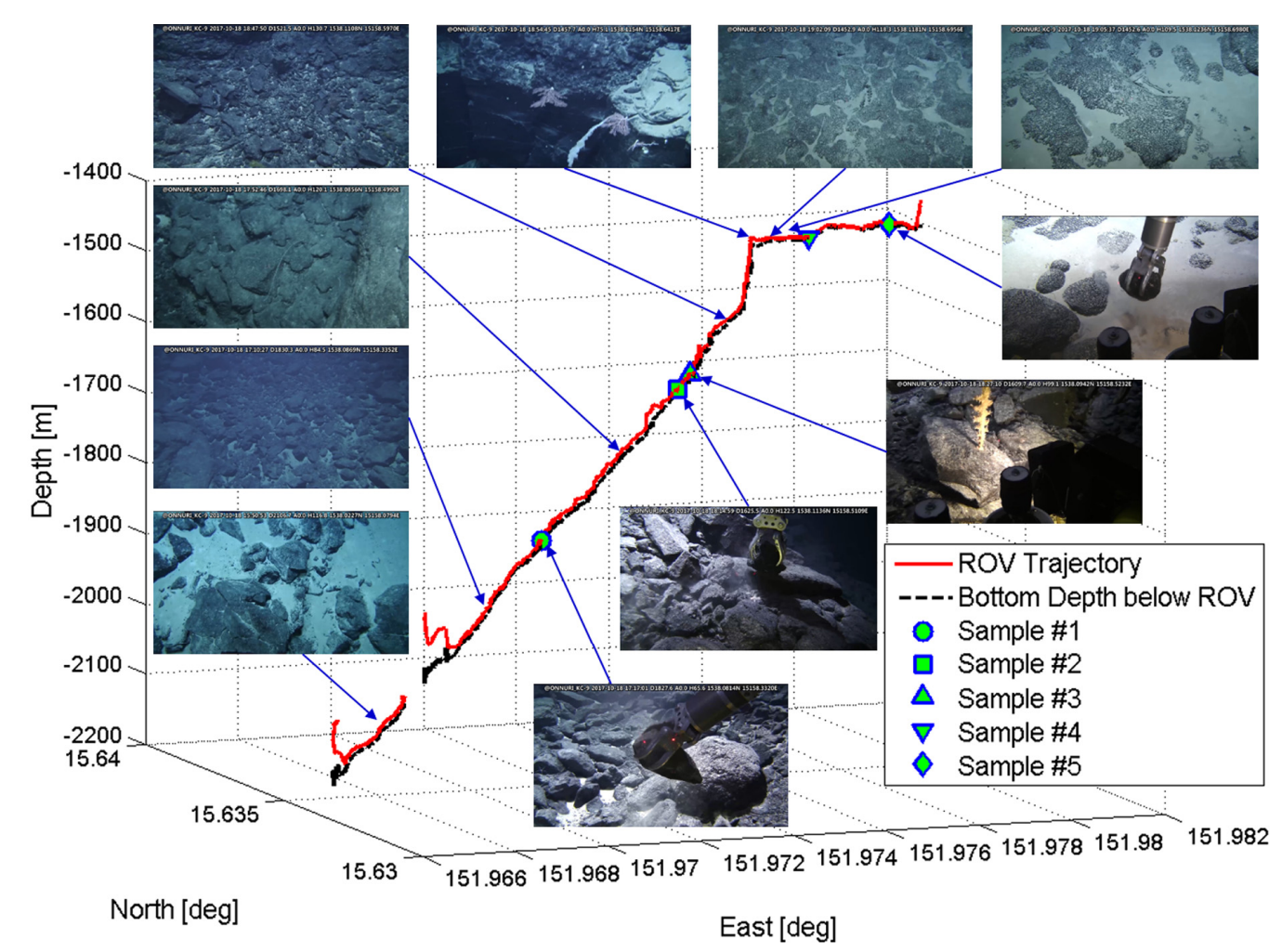

Fig. $83 \mathrm{D}$ trajectories and representative images of OSM11 survey

Fig. 8은 OSM11 해저산 탐사 궤적을 3차원으로 나타낸 그림이 며, 각 지점별로 망간각 부존상태를 알 수 있도록 대표적인 장면 을 포함하였다. 그림에서 붉은 실선은 해미래 궤적이며, 검은 점 선은 해미래 수심에 고도측정값을 더하여 얻은 해저면 프로파일 이다. 그림에서 해저산 정상부는 약 $50 \mathrm{~m}$ 높이의 수직 절벽이며, 이후에는 평탄면임을 보인다. Fig. 8의 탐사궤적 빈 구간(수심 $2,000 \mathrm{~m}$ 부근)은 선상의 전원실 주파수변환기 과열로 인해 전원이 차단되어 기록이 없는 구간이다. 이 기간 동안은 해미래의 안전 을 위한 긴급조치가 이루어졌다. 긴급조치에 대한 자세한 내용은 4.1장에서 다루었다.

\subsection{OSM07 해저산 중턱 평탄면 탐사}

OSM07 해저산 중턱 수심 $2,500 \mathrm{~m}$ 의 평사면 탐사는 약 $2.0 \mathrm{~km}$ 수 평거리를 이동하며 해저 퇴적토 상태를 관측하였다. 탐사는 두 지 점 $\left(52^{\circ} 23^{\prime} 00.7003^{\prime \prime} \mathrm{E} / 16^{\circ} 48^{\circ} 07.3622^{`} \mathrm{~N}, 152^{\circ} 21^{\prime} 00.2183^{\circ} \mathrm{E} / 16^{\circ} 49^{\prime} 19\right.$. $2782^{` N}$ )을 기준으로 정해 이 방향을 따라 이동하며 특이 지점에서 퇴적토 시료채집을 시도했다. Fig. 9는 X-Y 평면의 해미래 이동경 로를 나타낸다. 관측은 고도 $2 \mathrm{~m}$ 를 유지하며 이루어졌다. 이 지역은 해미래가 직선거리로 $2 \mathrm{~km}$ 이동하는 동안 수심변화가 거의 없이 평탄하며, 관측 시작지점과 종료지점의 심도 차이가 $7 \mathrm{~m}$ 에 불과했 다(심도 변화는 Fig. 11 참조).

Fig. 10은 OSM07 평탄면의 퇴적토를 나타내는 파일럿 - 수직 카메라 영상이다. 해저면은 관측 전 구간에 동일한 형상의 물결 무늬 퇴적토로 덮여있다. Fig. 11은 OSM07 해역 탐사 궤적을 3차 원으로 나타낸 것으로써, 우측 시작지점과 중간지점, 퇴적물 시 료채집 지점 및 종료지점 부근의 해저면 영상을 나타낸다. 이동 중 두 지점에서 푸시코어를 이용하여 퇴적토 채집을 시도하였다.
퇴적토 깊이는 $10 \sim 20 \mathrm{~cm}$ 정도이며, 기저면은 단단한 암반이었다. 로봇팔을 이용한 푸시코어를 약 $10 \mathrm{~cm}$ 이상 누르면 해미래가 들 리는 현상이 발생했다. 또한 퇴적토는 점도가 매우 낮아 코어를 바닥에서 들어 올리자마자 흘러내렸다. 퇴적토 채집 2차 시도에 서는 시료가 코어 내부에 만충되도록 코어를 연속하여 해저면에

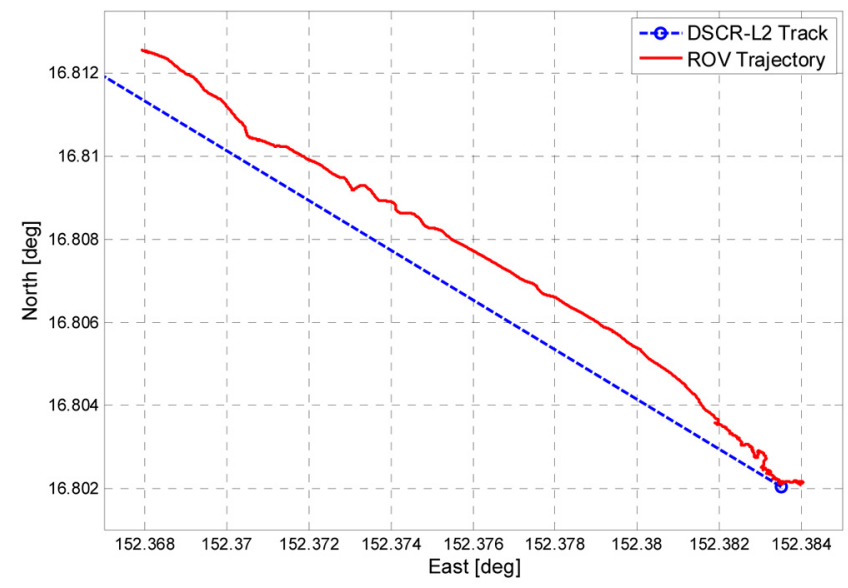

Fig. 9 X-Y plane trajectory of Hemire in the OSM07 survey

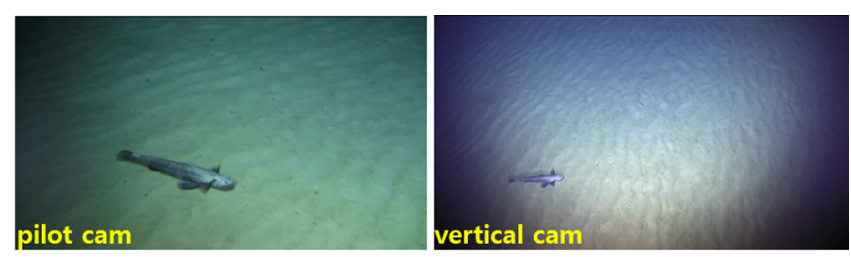

Fig. 10 Bottom sediment at the mid-flat area of OSM07 


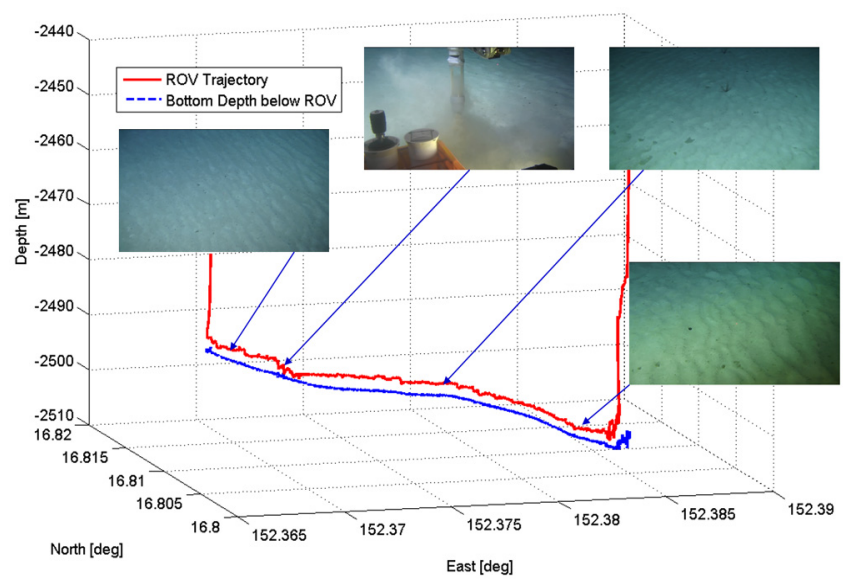

Fig. 11 3D trajectories and representative images of OSM07 survey

꽂는 방법을 시도하였다. 하지만 이 역시 퇴적토 시료가 흘러내 렸다. 이 지역과 같이 퇴적물 점성이 낮고 퇴적층 두께가 얇은 경 우의 퇴적토 채집은 국자형태로 제작된 스쿠프(Min et al., 2016; Kim et al., 2017)가 더 효과적일 것으로 판단된다.

\section{ROV 운용성 및 탐사성능 검토}

\subsection{ROV 공급전원 차단시 긴급조치}

본 절에서는 해미래에 전원이 차단된 위험 상황에서의 긴급 대 처법을 간략히 설명한다. Fig. 5 는 6,100 초 근처에서 약 10 분간 전 원 블랙아웃이 발생했음을 나타낸다. Fig. 5의 세 번째 그림은 탐 사시간동안 ROV의 심도와 고도를 나타낸다. 그림의 6,100 초에서 6,700 초 사이에 약 10 분간 빈 구간이 있다. 이 시간 구간이 선상 전원변환실의 주파수변환기 과열로 인해 해미래 전원이 차단된 순간이다. 주파수변환기에서 대부분의 열은 IGBT(Insulated gate bipolar transistor) 소자에서 발생하는데(Choi et al., 2011), 이 소자 가 과열되면서 안전을 위해 해미래 전원이 차단됐다.

전원이 차단된 비상상황에서의 두 가지 긴급조치가 필요하다. 첫째는 과열된 장치를 냉각시키는 것이고, 둘째는 전원이 재공 급되기까지 ROV를 안전하게 유지하는 것이다. 장치냉각을 위 해 전원실의 모든 문을 열어 전원실을 환기시키며 에어컨 냉기 가 IGBT에 직접 공급되도록 덕트가 연결된 순환팬을 이동 설치 하고, 주파수변환기의 온도센서에 의한 에러가 해제되기를 기 다린다. 전원이 공급되지 않는 시간 동안 해미래를 안전한 상태 로 유지하는 것은 대단히 중요하다. 전원이 차단되면 해미래는 제어력을 잃게 되고 자체 양성부력으로 인해 부상을 하게 된다. 이때에 이를 방치하면 해미래가 해누비 보다 위에 위치하게 된 다. 해누비는 모선과 1차 케이블로 연결되어서 모선운동 영향으 로 상하운동을 지속하는데, 부상하는 해미래가 해누비와 충돌 할 가능성이 높고, 충돌을 피하더라도 2 차 케이블이 해누비에 엉키는 사고를 피할 수 없다. 이를 피하기 위하여 지원모선을 저속 $(0.5 \mathrm{~m} / \mathrm{s}$ 이하)으로 전진시키며, 해미래가 자체 양성부력으로 부상하는 속도보다 빠른 속도인 $5 \sim 10 \mathrm{~m} / \mathrm{min}$ 로 윈치케이블을 감 아서 해누비를 서서히 상승시켰다. 모선을 전진시키며 윈치를 감는 것은 지원모선이 해누비 디프레서를 1 차 케이블로 견인하 여 위험지역(해누비가 해미래와 엉킬 수 있는 영역)을 벗어나게
만드는 것으로써, 해미래가 해누비 아래에 항상 위치하도록 안 전상태를 유지하는 것이다.

전원이 재공급되면 모선과 윈치를 정지시켜 정지상태에서 해 미래 상태를 재점검한다. 안전상태가 확인되면, 윈치케이블을 풀 어 해누비를 하강시킨다. 이때 해미래는 심도 유지 제어를 한다. 해누비와 수심이 같아지면 탐사모드로 전환하여 탐사고도까지 해미래와 해누비를 재잠항한다. 그림에서 해미래 심도값(ROV trajectory)은 하강곡선을 나타내고, 해저면 고도(Bottom depth below ROV)가 6,700초 이후부터 기록되는 것을 확인할 수 있다.

\subsection{1차 케이블 고정법 변경 영향 분석}

해미래 시스템에서 수중에 들어가는 해미래와 해누비는 중성 부력의 2 차 케이블로 연결되어 있고, 해누비는 지원모선과 음성 부력의 1 차 케이블로 연결되어 있다. 지금까지 1 차 케이블 종단 은 힌지 형태의 터미네이터가 해누비에 체결되어 있었다(Lee et al., 2007; Ryu et al., 2007). 힌지고정 터미네이터는 일정 범위에 서 피치운동이 자유로우나 종운동(Roll)과 선수각운동(Yaw)이 구속되는 방식이다. 잠항 - 부상 시뿐만 아니라 심해저 탐사 시 에도 모선 운동이 해누비에 직접 전달되므로, 해누비와 터미네 이터의 상호 운동구속에 의하여 1 차 케이블 종단에 국부 3 축 모멘트가 발생할 수 있다. 따라서 이번 탐사에서 Fig. 2의 오른 쪽 그림과 같이 해누비 상단에 네 방향으로 체인을 연결하여 1 차 케이블 터미네이터와 해누비 사이의 종/횡/선수각 상대운동 이 구속되지 않도록 연결부를 개선하였다.

터미네이터 연결부 변경에 따른 영향을 분석하기 위해 2016년 마리아나 해저 열수분출공 탐사(Lee et al., 2016)와 해저산 망간 각 탐사에서 해누비 각운동을 비교하였다. 2016년 마리아나 열수 분출공 탐사는 1차 케이블이 해누비에 힌지고정 되었고, 2017년 망간각 탐사는 체인연결 되었다. 두 탐사는 온누리호를 모선으로 운용되었으며, 해상상태는 수동위치제어가 가능한 유사 조건이 다. 두 운동 데이터는 불규칙한 해상에서 실측되었으므로 통계적 으로 특성을 검토하였다. 하강/탐사모드전환/해저탐사/상승 등 운용조건별로 최대운동이 발생하는 구간에 대해 일정시간을 정

Table 2 Roll motion of the depressor depending on connection types

\begin{tabular}{cccccccc}
\hline \multirow{2}{*}{ Roll } & \multicolumn{2}{c}{ Mean [deg] } & \multicolumn{2}{c}{ Std. Dev. [deg] } & \multicolumn{2}{c}{ Peak [deg] } \\
\cline { 2 - 8 } & Hinged & Chain & Hinged & Chain & Hinged & Chain \\
\hline Descend & 2.32 & 2.91 & 0.35 & $\mathbf{1 . 5 8}$ & 4.1 & 9.8 \\
Mode change & 4.79 & 4.25 & 1.12 & $\mathbf{5 . 2 8}$ & 5.9 & 31.8 \\
Survey & 1.89 & 2.91 & 0.26 & $\mathbf{1 . 5 8}$ & $\mathbf{1 2 . 1}$ & 9.8 \\
Ascend & 3.19 & 7.19 & 0.67 & $\mathbf{2 . 6 4}$ & 5.8 & $\mathbf{2 5 . 4}$ \\
\hline
\end{tabular}

Table 3 Pitch motion of the depressor depending on connection types

\begin{tabular}{cccccccc}
\hline \multirow{2}{*}{ pitch } & \multicolumn{2}{c}{ Mean [deg] } & \multicolumn{2}{c}{ Std. Dev. [deg] } & \multicolumn{2}{c}{ Peak [deg] } \\
\cline { 2 - 7 } & Hinged & Chain & Hinged & Chain & Hinged & Chain \\
\hline Descend & -0.60 & -0.51 & 0.96 & $\mathbf{2 . 3 4}$ & 4.3 & $\mathbf{1 2 . 3}$ \\
Mode change & 5.08 & 2.10 & 2.94 & $\mathbf{7 . 3 4}$ & 10.2 & $\mathbf{4 7 . 0}$ \\
Survey & -3.15 & -0.51 & 0.86 & $\mathbf{2 . 3 4}$ & $\mathbf{1 8 . 0}$ & 12.3 \\
Ascend & 1.17 & 1.15 & $\mathbf{4 . 2 4}$ & 3.22 & 16.9 & $\mathbf{1 8 . 2}$ \\
\hline
\end{tabular}




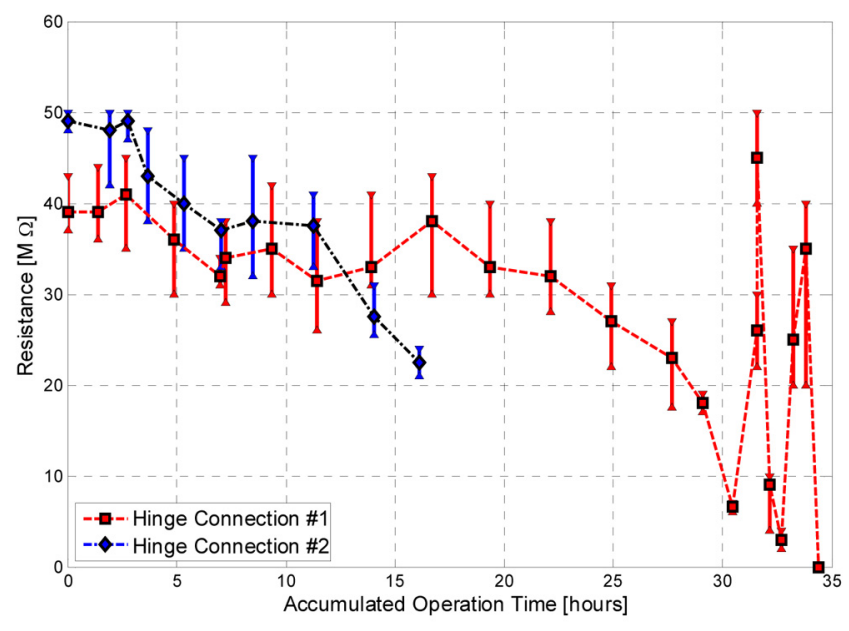

Fig. 12 GFM variation of the remote control unit(RCU)

하고, 각각 표준편차와 최대값을 비교하였다. 네 가지 운용조건 에 대한 평균, 표준편차, 최대값이 Table 2 및 Table 3 과 같다.

체인고정은 힌지고정 터미네이터에 걸리던 롤과 선수각 방향 의 구속이 풀려 해누비의 롤운동과 선수각 운동이 대부분의 조 건에서 크게 증가한 것을 볼 수 있다. 특히 롤운동은 표준편차 가 4.5 배 증가했으며 피크 값이 5.4배가 증가했다. 두 탐사의 해 상상태가 유사한 것을 고려하면, 힌지고정에 의한 롤방향 구속 이 풀려서 운동이 증가한 것으로 판단된다. 특히 탐사모드 전환 시 큰 피크 값을 보이는 것은 해미래가 해누비 아래로 이동하 며 해미래-해누비 사이의 2 차 케이블에 장력이 걸리며 두 선체 가 상호작용으로 운동하는 순간이다.

해누비의 롤/피치 운동을 구속하면 1차 케이블 연결부에 반복하 중이 걸리게 된다. 1 차 케이블 터미네이터에 걸리는 반복하중은 터미네이터의 절연특성에 영향을 미친다. 따라서 해누비 운동이 구속되지 않는 것이 1차 케이블 수명에 유리하다. Fig. 12는 2016 년 봄에 마리아나 해저 열수분출공 탐사 시 측정된 절연저항 값을 나타낸다. 해미래 운용시간이 누적되면서 절연저항이 감소함을 알 수 있다. 그림에서 수직선은 저항변동 편차를 나타내며, 모선 운동이 크거나 해미래가 해누비에 상호간섭이 일어나는 경우에 작은 값으로 떨어지며 변동하였다. 절연저항이 $3 \mathrm{M} \Omega$ 이하에서 일 시적인 통신 장애가 일어나며 저항이 더욱 저하하면 통신장애가 복구되지 못했다. 알키안 Dive-6에서 발생한 통신두절은 절연저항 파손이 원인으로 파악되었다(Lee et al., 2016).

체인고정이 케이블 수명연장에 유리하다는 가설을 증명하기 위해서는 RCU(Remote control unit) GFM(Ground fault monitor)을 기록하는 것이 필수이다. 본 망간각 탐사에서는 이 데이터가 기 록되지 못했지만, 운용 중 전원변환실의 주파수변환기에 모니 터링 된 데이터에 의하면 절연저항이 탐사 전 기간에서 양호한 것으로 나타나 위 결론이 타당한 것으로 판단된다.

\section{3 추진기 내압용기 방열핀 영향}

해미래 전동모터는 $5 \mathrm{HP}(3.73 \mathrm{~kW})$ 이며, 추진기용 6 개, 유압펌프 구동용 1 개 등 7 개 모터드라이버가 사용된다. 당초 모터드라이버 는 방열을 위해 반구형 알루미늄 내압용기에 방열판을 연결하는 구조였다(Lee et al., 2007). 이후 반구형 내압용기의 커넥터 탈부
착이 불편하여 실린더 형태로 변경하였고 이로 인해 모터드라이 버 방열효과가 저하되었다. 이를 개선하기 위해 이번탐사에는 2 장에서 설명된 것과 같이 실린더형 내압용기 뚜껑에 히트파이프 를 이용한 냉각 플러그 4개를 설치하였다. 냉각 플러그를 부착함 으로써 탐사 전 구간에서 모터드라이버가 과열되지 않고 정상 작 동했으며, 6 개 모터를 $900 \mathrm{rpm}$ 범위에서 풀가동하여도 모터 드라 이버에 에러가 발생되지 않고 정상적인 성능을 유지하였다.

\section{4 해미래 이동속도}

OSM07 해역 탐사는 해저산 중간 평탄면을 이동하며 퇴적토 관측이 임무이다. 이 지역에서 해미래는 빠르게 이동하며 특이 지역에서 정밀관측과 시료 채집이 이루어졌다. 고도변화가 거 의 없이 평탄한 지역이므로 해미래 이동시 심도 유지, 선수각 유지 기능을 활성화하고 파일럿은 해누비 위치를 모니터링하며 전진속도를 조종하였다. Fig. 13 상단은 탐사중 11,800 12,800초 사이의 $V_{X}, V_{y}, V_{z}$ 속도를 나타내며, 하단은 6 개 추진기의 속 도(분당 회전수)를 나타낸다. 해미래는 12,540 초 구간에서 최대 $0.72 \mathrm{~m} / \mathrm{s}$ 속도를 유지했으며, 이때 전진방향 추진기 속도는 900rpm을 나타냈다. 수직추진기 속도에 스파이크 형태의 명령 이 생성된 것은 양성부력의 해미래 심도제어를 위해 오프셋이 있는 $\mathrm{PD}$ 제어기가 작동하며 심도를 깊게 제어하는 명령에 따라 추진기 역회전 명령이 생성된 것으로 보인다.
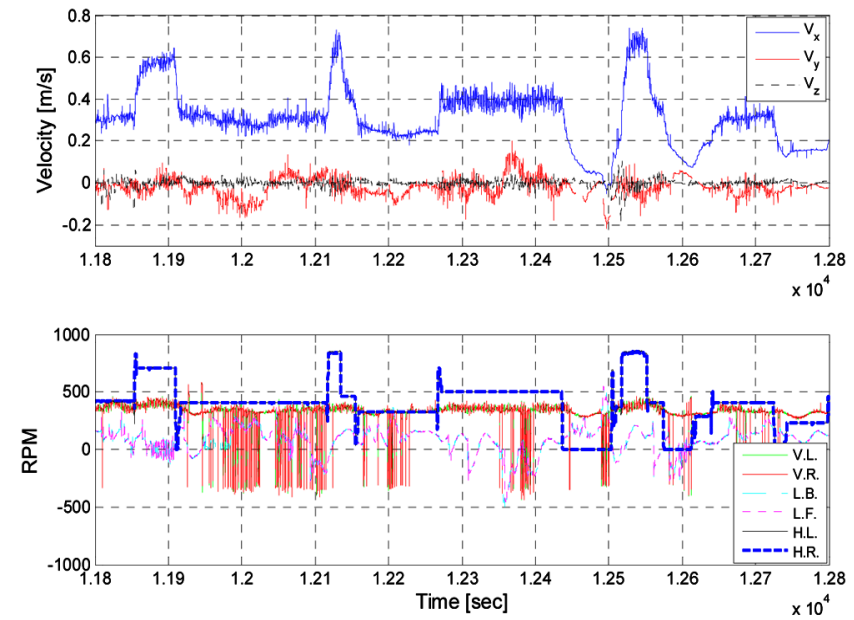

Fig. 13 Velocity of Hemire in the flat bottom survey at OSM07

\subsection{USBL 블랙아웃과 수중복합항법 위치추정}

본 탐사에 적용된 수중항법은 USBL(Ultra short baseline)과 속 도.자세·심도 센서를 융합한 복합항법을 이용하였다(Lee et al. 2017). 이 수중항법은 관성센서를 이용하는 복합항법(Lee et al. 2003)보다 간단하고, ROV와 같이 가속도 변화가 심하지 않는 잠수정의 수중항법에 적합하며, 센서 신호의 아웃라이어와 블 랙아웃에 강인한 장점을 갖는다. OSM11 해역탐사시 USBL 신 호취득에 블랙아웃이 발생했다. 마리아나 알키안 열수분출공 탐사에서 블랙아웃이 발생했었으며 동일한 증상이 이번 탐사에 도 발생했다(Lee et al., 2016; Lee et al., 2017). 해미래에 사용되 고 있는 Posidonia USBL은 2003년 구입하여 14년 경과된 상태 로 프로세서가 부정기적으로 다운되는 증상을 보인다. Fig. 14 


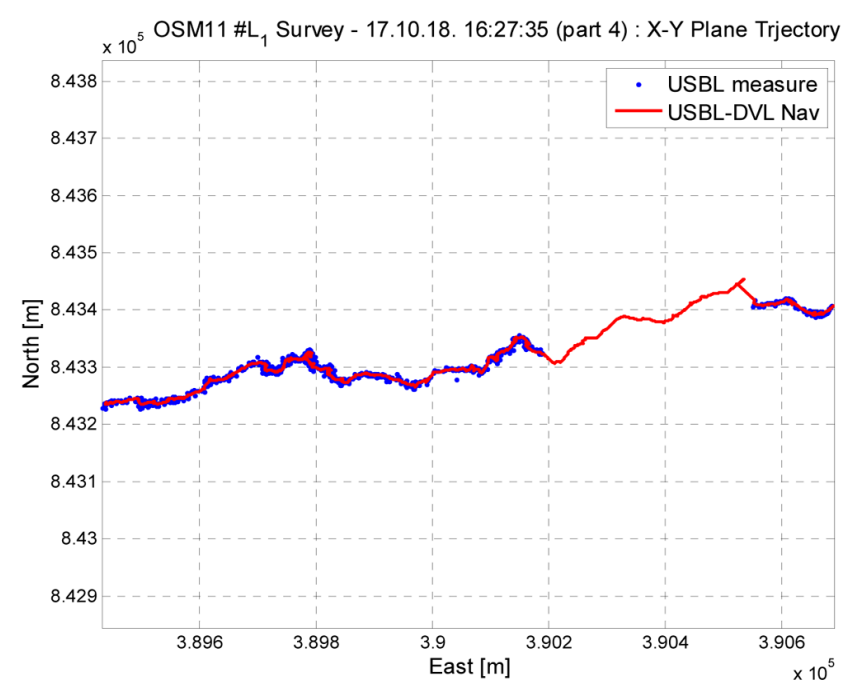

Fig. 14 USBL measurements with blackout \& the INS
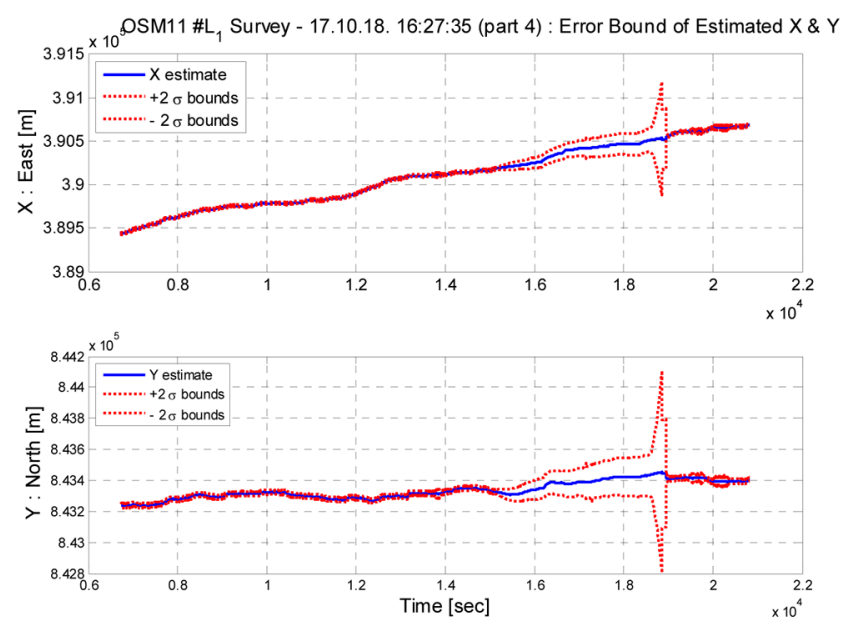

Fig. 15 Error bounds $(2 \sigma)$ of the USBL-DVL INS navigation

는 USBL 신호가 장시간 취득되지 않은 상태에서 수중복합항법 알고리듬이 추정한 위치 궤적을 보인다. 그림에서 USBL 신호 복귀 후 수중항법시스템의 추정위치가 신속하게 보정되며 정상 위치로 수렴하여 센서신호 블랙아웃에 강인한 특성을 보였다.

Fig. 15 는 추정위치와 $95 \%$ 신뢰 오차범위를 나타낸다. 블랙아 웃은 1 시간 10 분 동안 발생했고, USBL 신호 복구 후 보정된 위 치오차가 약 $40 \mathrm{~m}$ 이다. USBL 블랙아웃 시간 경과에 따라 오차 범위는 선형적으로 증가했다. 해미래가 해저산 정상에서 샘플 링을 위해 착지한 상태에서는 DVL(Doppler velocity log)이 측정 가능한 최소 고도 이내에 들어와 DVL도 블랙아웃 상태가 되었 다. 이 구간에서는 위치추정 오차 범위가 급격히 증가하였다. USBL 위치측정은 해미래 운용에 필수이므로 프로세서를 수리 업그레이드하거나 교체하는 것이 요구된다.

\section{6 경사면 작업시 자세유지}

해미래가 탐사한 OSM 해저산은 경사면 기울기가 평균 33 도 에 이른다. 이런 경사지에서 암석시료를 채집하기 위하여 파일 럿은 ROV 본체를 경사면 암석에 툴슬레드 전방 하단을 밀착시 켜야 한다. 이때 잠수정 본체의 자세를 적정하게 유지하면서,
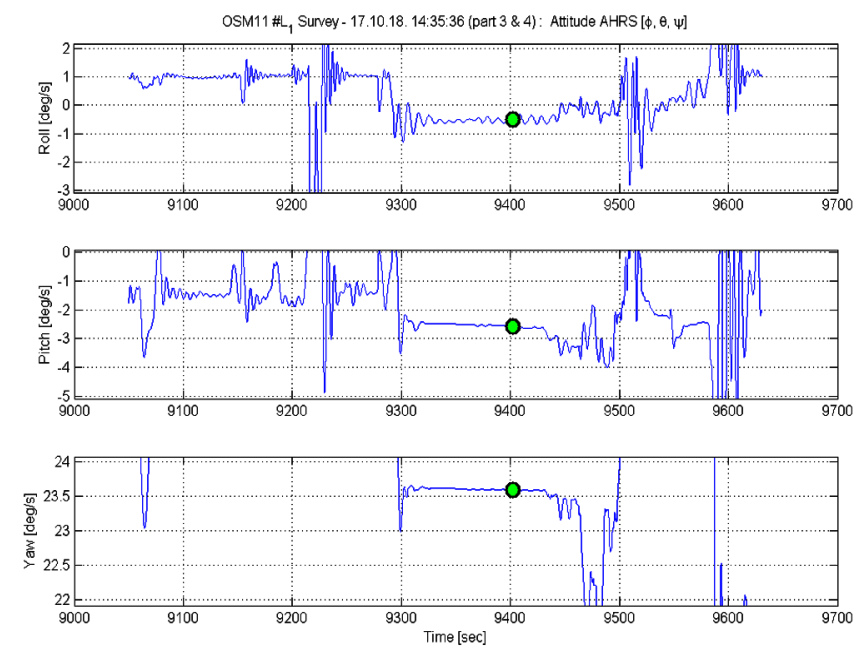

Fig. 16 Attitude of Hemire while collecting the rock sample \#1

로봇팔 작업시 발생하는 반력을 이길 수 있도록 충분한 접지력 을 발생시키는 것이 요구된다. 이를 위하여 해미래 파일럿은 전 진 추진력을 부가하며 동시 수직하강 추진력을 발생시켰다. 이 는 경사면에 수직한 방향으로 접지력이 생성되며 해미래 자세 가 평형을 유지하는 상태를 만들 수 있다. Fig. 16은 암석시료 \#1을 채집하는 과정의 해미래 롤/피치/선수각 변화를 나타낸다. 착지 후 피치각이 음의 방향으로 증가해(Nose down), 전진추진 력에 의한 모멘트가 수직하강 추진력에 의한 모멘트보다 큰 것 을 알 수 있다. 경사면 작업 시 툴슬레드 전방이 피봇 상태이므 로 롤운동을 보였으나 크기는 작다. 'o'표시는 암석시료 \#1 채 집을 위한 로봇팔 작업시점을 나타낸다.

\subsection{3차원 영상 생성 및 분석}

임무 중 하나인 경사면의 연속촬영은 지형에 따른 망간각의 분포특성을 파악하기 위함이다. 이를 위해서는 영상 이미지의 모자이크 처리가 분포특성을 파악하는데 효율적일 것이다. 본

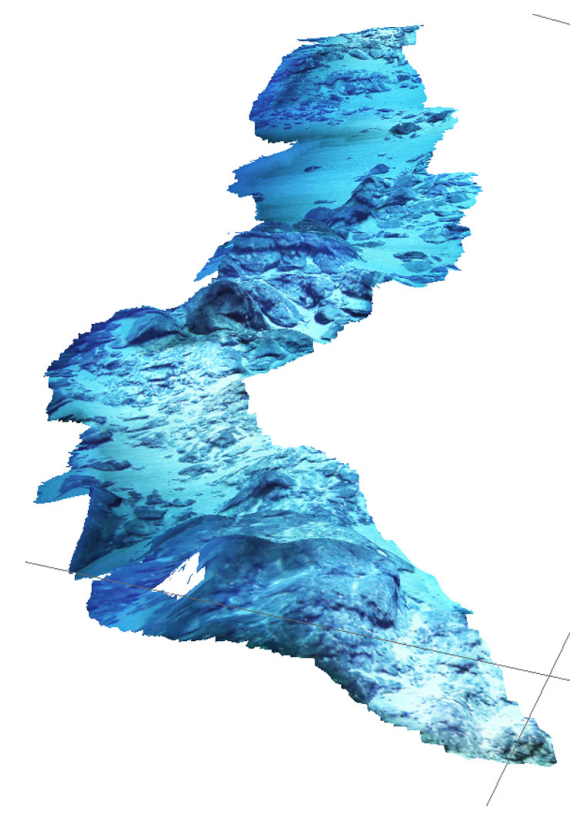

Fig. 17 3D mosaic images 


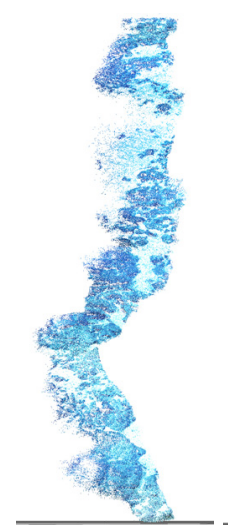

(a)

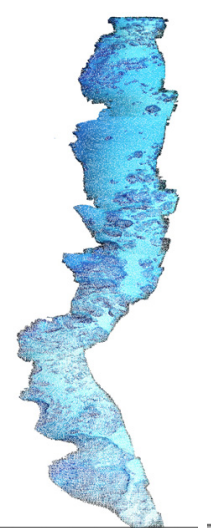

(b)

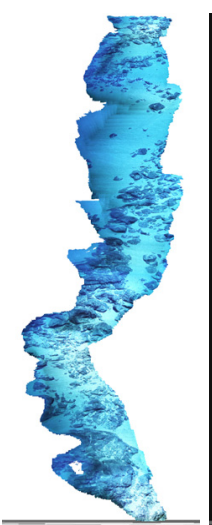

(c)

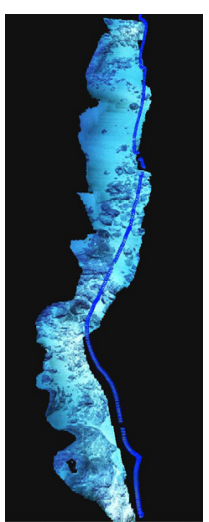

(d)
Fig. 18 3-D image mosaicking process

논문에서는 샘플로 첫날 OSM11 광구에서 해저산의 사면에서 정상부로 향하면서 촬영한 약 4분간의 영상이미지를 Fig. 17과 같이 이미지 합성과 3 차원화를 수행했다.

이에 사용된 프로그램은 상용프로그램인 3DF Zephyr(3Dflow srl, 2013)를 이용하였으며, Fig. 18에서 그 처리 순서를 나타내 고 있다. 제일 좌측 그림은 총 378 장의 사진을 합성한 3 차원 점 구름(Point cloud) 처리결과이며, 두 번째는 고밀도 점구름(Dense point cloud)을 생성한 결과를 나타내고, 세 번째 그림은 Mesh 처리한 3 차원 이미지데이터 결과이다. 마지막 네 번째 그림은 합성에 사용된 카메라의 위치를 나타낸 것으로 향후 해미래의 이동 궤적과 비교하는 연구가 필요하겠다.

\section{8 멀티빔소나(MBS, Multi-beam sonar) 이미지 분석}

해미래 선미에 장착되어 있는 멀티빔소나(Park et al., 2017)를 이용하여 해저지형에 대한 프로파일링 임무 역시 동시에 수행 하였다. Fig. 19는 OSM11 지역의 프로파일링 결과이다. 해미래

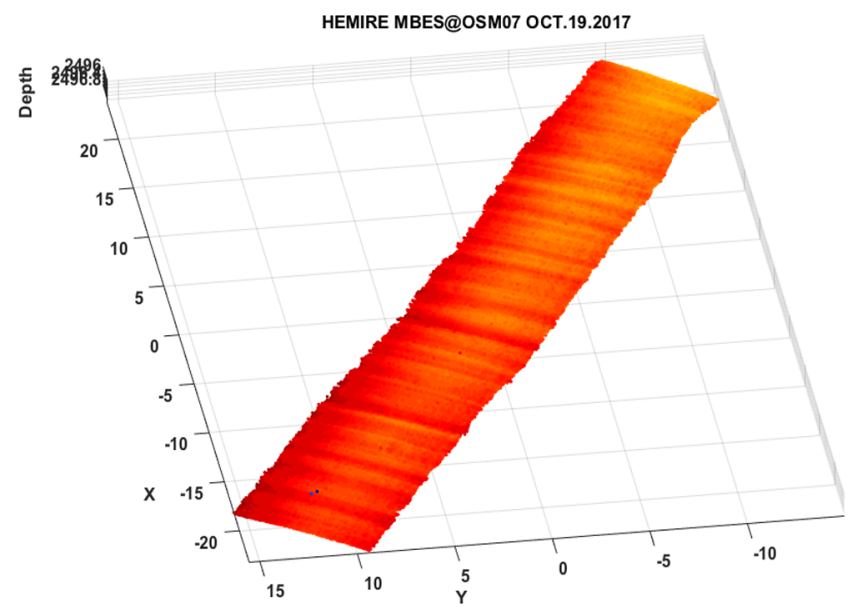

Fig. 20 MBS Profiling result at the mid-flat zone of OSM07

가 좌하단 수심 약 $2,150 \mathrm{~m}$ 에서 우상단으로 약 $2,047 \mathrm{~m}$ 까지 상승 하며 계측하였다. 청색 실선은 해미래의 궤적을 나타내며, 노란 색 삼각형은 해미래의 방향을 묘사한 것이다. $\mathrm{X}$ 축과 $\mathrm{Y}$ 축은 실 제 항해한 거리를 가늠하기 쉽도록 중간지점을 원점으로 하여 오프셋 시켜 표시하였다. Fig. 19에서의 실제 시작위치는 북위 $15.6336^{\circ}$, 동경 $151.9664^{\circ}$ 이었다.

OSM07해역에서의 프로파일링은 비교적 평탄한 지역에서 이 루어졌다. Fig. 20이 그 일부를 보여주고 있다.

\section{5. 결 론}

본 논문에서는 기존의 연구선 단독 탐사에서 가지고 있던 해 저 사면의 정밀 영상촬영과 정위치 시료채집의 한계를 $\mathrm{ROV}$ 를 통해 극복한 국내 첫 탐사 사례를 소개했다. 특히, 이번 탐사에 서는 1 차 케이블 고정법 변경과 추진기 내압용기의 방열구조를
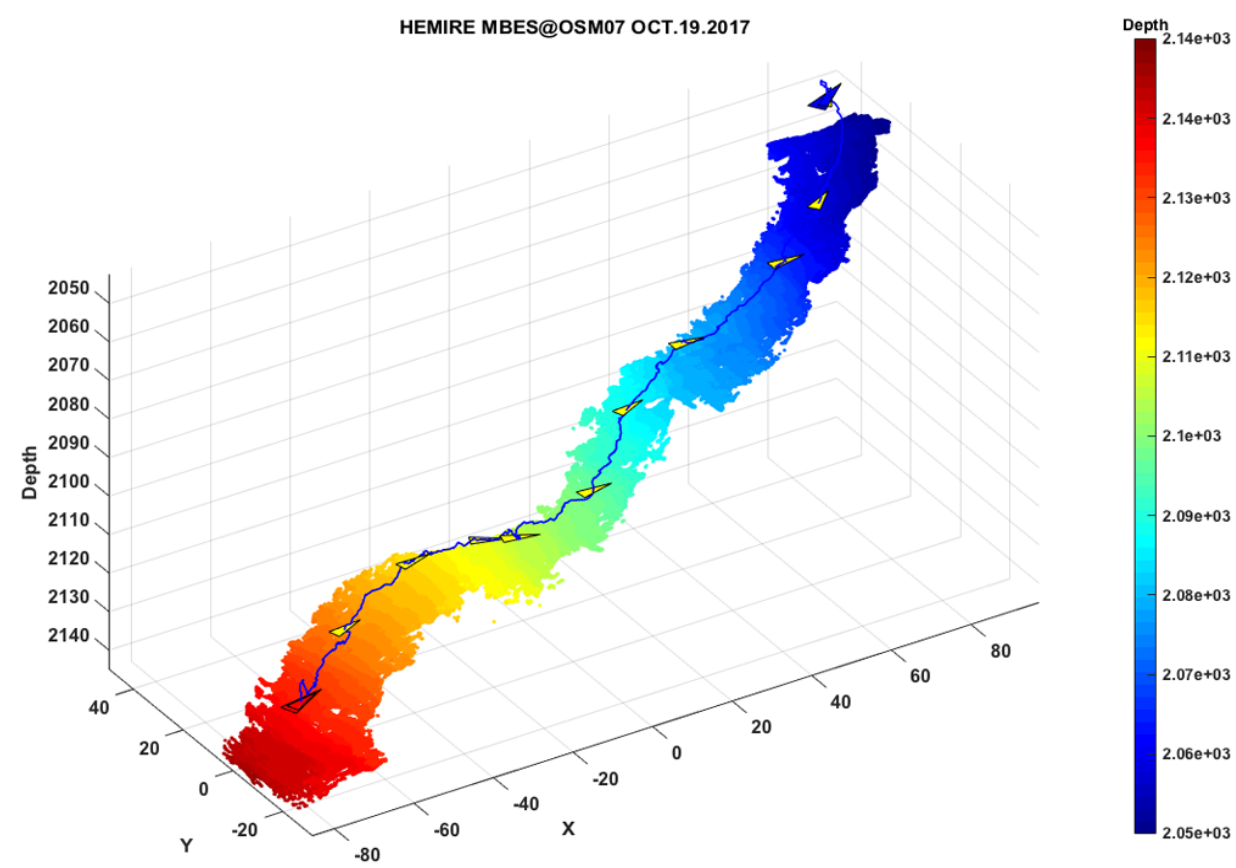

Fig. 19 MBS Profiling result at the slope of OSM11 
개선하여 심해에서 해미래를 안정적으로 운용할 수 있었고, 두 해저산 지역에서 각각 4 시간 10 분과 3 시간 16 분간 영상촬영에 성공했다. 해저 탐사중 해양과학자가 육안으로 해저면을 관측 하며 필요로 하는 망간각 시료 5 개를 정위치 샘플링하여, 기존 의 탐사방법에 비해 탐사위치 정밀도와 정확도가 크게 향상되 었다. 또한, 추진기 앰프의 냉각을 위한 내압 하우징의 방열구 조를 개선함으로써 모터 회전수를 증대시켜 고출력으로 심해탐 사를 수행할 수 있었다. 방열구조 개선으로 해미래 시스템의 소 비전력이 증가했다. 그러나 소비전력 증가는 선상 전원변환실 의 주파주변환기가 과열되는 원인이 되었고, 이로 인해 해저탐 사 중에 해미래 전원이 차단되는 문제가 발생했다. 주파수변환 기는 현재 공냉식 냉각에만 의존하고 있다. 열대의 더운 지역에 서 에어컨 한 대와 덕트 연결 순환팬으로는 현 시스템을 충분 히 냉각시키지 못하는 것을 이번 탐사에서 확인했다. 향후에는 히트파이프를 이용한 수냉식 냉각방식을 IGBT 소자 냉각에 적 용하여 효율적인 냉각이 되도록 공조시스템을 개선할 필요가 있다. 마지막으로 해저면 정밀 영상을 이용한 이미지 합성결과 는 지질학자들에게 필요한 해저산 사면의 피복 특성연구에 큰 도움이 될 것으로 기대된다.

\section{후 기}

본 연구는 선박해양플랜트연구소의 주요사업인 “극지 환경을 고려한 수중음향기반 위치추정 및 해상 항법 기초 기술 연구" (PES9230)와 "해양 장비의 실해역 데이터 정합 기술에 관한 연 구”(PES9510) 그리고 한국해양과학기술원의 해양수산부 국가연 구개발사업인 “남서태평양 및 인도양 해양광물자원(해저열수광 상, 망간각) 개발”(PM60320)에 의해 수행되었습니다. 본 연구를 수행한 탐사에는 한국해양과학기술원의 유찬민 박사와 김병찬 연구원이 공동으로 참여하였음을 밝힙니다.

\section{References}

McDonald, G., Naiman, M., 2002. Heat-Transfer Advances for Submerged Oceanographic Systems. Proceedings of the MTS/IEEE Oceans 2002, 4, 2045-2049.

Baek, H., Shim, H.-W., Lee, P.-M., Jun, B.-H., Park, J.-Y., Yoo, C.-M., Kim, B,-C., 2017. Exploration of Ferromanganese Crusts of the Western Pacific Seamont Using Hemire ROV. Proceedings of Korean Marine Robot Technology Society in Pohang, 23-28.

Choi, J.-H., Oh, S.-Y., Choi, J.-S., Yang, S.-H., Kim, D.-K., 2011. Water Cooling Pipe Optimal Design for Heat-Dissipation of Wind Power Converter System. Power Electronics Annual Conference. 485-486.

Kim, W.-S., et al., 2017. Development of Manned Submersible and Unmanned Underwater Vehicle, and Supporting Infrastructure. Research Reports in the KIOST, BSPM59620-11346-7.

Min, W.-G., Kim, J., Kim, W.-S., Kim, D.-S., Lee, P.-M., Kang,
J.-H., 2016. Deep-sea Floor Exploration in the East Sea Using ROV Hemire. Journal of the Korea Academic-Industrial Cooperation Society. 17(4), 222-230.

Moon, J.-W., et al., 2014. A Study on th Development of Marine Biological Resources(Hydrothermal Polymetallic Sulphides. Cobalt-rich Ferromanganese Crusts) in the Indian and SouthWest Pacific Ocean. Research Reports in the KIOST, BSPM57580-10458-5.

Moon, J.-W., et al., 2015. A Study on th Development of Marine Biological Resources(Hydrothermal Polymetallic Sulphides. Cobalt-rich Ferromanganese Crusts) in the Indian and SouthWest Pacific Ocean. Research Reports in the KIOST, BSPM58080-10722-5.

Moon, J.-W., et al., 2016. A Study on th Development of Marine Biological Resources(Hydrothermal Polymetallic Sulphides. Cobalt-rich Ferromanganese Crusts) in the Indian and SouthWest Pacific Ocean. Research Reports in the KIOST, BSPM58540-10946-5.

Park, J.-Y., Shim, H.-W., Lee, P.-M., Jun, B.-H., Baek, H., Kim, B.-H., Yoo, S.-Y., Jeong, W.-Y., 2017. Multi-beam Echo Sounder Operations for ROV Hemire - Exploration of Mariana Hydrothermal Vent Site and Post-Processing. Journal of Ocean Engineering and Technology, 31(1), 69-79.

Lee. C.-M., Lee, P.-M., Seong, W.-J., 2003. Underwater Hybrid Navigation Algorithm Based on an Inertial Sensor and a Doppler Velocity Log Using an Indirect Feedback Kalman Filter. Journal of Ocean Engineering and Technology, 17(6), 83-90.

Lee, P.-M., et al., 2007. Development of an Advanced Deep-Sea Unmanned Underwater Vehicle(1st Phase). Research Reports in the KIOST, UCM01240-07035.

Lee, P.-M., Jun, B.-H., Baek, H., Kim, B.-H., Shim, H.-W., Park, J.-Y., Yoo, S.-Y., Jeong, W.-Y., Baek, S.H., Kim, W.-S., 2016. Explorations of Hydrothermal Vents in the Southern Mariana Arc Submarine Volcanoes using the ROV Hemire. Journal of Ocean Engineering and Technology, 30(5), 389-399.

Lee, P.-M., Shim, H.-W., Baek, H., Kim, B.-H., Park, J.-Y., Jun, B.-H., Yoo, S.-Y., 2017. Navigation System for a Deep-sea ROV Fusing USBL, DVL, and Heading Measurements. Journal of Ocean Engineering and Technology, 31(4), 315-323.

Ryu, S., Baek, H., Jun, B., Lee, P., Lee, C., Choi, H., Li, J., Kim, K., Cho, S., Kim, D., Park, D., Bowen, A., 2007. Launch, Dive, and Recovery of Two-bodied Deep-sea Unmanned Underwater Vehicles, Hemire and Henuvy. Post UT2007 Workshop, Shanghai, 1-7.

3Dflow srl, 2013. 3Dflow 3DF Zephyr User Manual 3.3. [Online] Available at: $<$ https://www.3dflow.net/technology/documents/ 3df-zephyr-documentation/> [Accessed 23 April 2018]. 